\title{
Performance Assessment of Domestic Wastewater Treatment Plants Operating on Different Technologies
}

\author{
Sudhir Kumar, Mahendra Pratap Choudhary
}

\begin{abstract}
Delhi, the most populated city in the country, is the capital of India. The huge population, urbanization and industrial processes contribute to degradation of water quality which is further aggravated by direct disposal of untreated domestic wastewater into the river Yamuna. In Delhi, the sewerage system is badly affected by improper management of the drainage system and insufficient installation of sewers in undeveloped as well as slum areas of the city which degrade the surface water quality of Yamuna River and create unhygienic conditions for the increasing population. In this study, three sewage treatment plants (STPs) have been selected which are situated at Najafgarh, Delhi Gate and Shahdara based on different technologies like Extended Aeration (EA), Biological Filtration and Oxygenated Reactor (BIOFOR) and Phytorid in order to assess the quality of wastewater before and after treatment and determining the removal efficiencies of various parameters. The study reveals that the performance of Delhi Gate and Shahdara STPs based on BIOFOR and Phytorid technologies are more efficient for the treatment of the municipal wastewater which can be further be safely disposed off into surface water and can be used for non-domestic purposes like irrigation, agriculture, cleaning of parks and streets. The effluent quality of Najafgarh STP based on EA technology is found to be less efficient as compared to the BIOFOR and Phytorid technologies. Hence, it is required to be operated and maintained properly with close supervision so as to achieve effluent quality standards as prescribed by the Indian standards.
\end{abstract}

Keywords: Sewage treatment plant, Extended Aeration, BIOFOR, Phytorid, Biochemical oxygen demand

\section{INTRODUCTION}

The river Yamuna is known as one of the polluted rivers in India and most of the polluted water enters in it from Delhi city. The main cause behind the polluted river Yamuna is the discharge of untreated wastewater, domestic as well as industrial wastewater into it, especially in Delhi city. Most of the polluted water enters in the stretch of Wazirabad to Okhla area which is the discharge of untreated wastewater in the

Revised Manuscript Received on February 05, 2020.

* Correspondence Author

Sudhir Kumar, M. Tech. (Environment), Department of Civil Engineering, Rajasthan Technical University, Kota, India. Email: sk3000484@gmail.com

Dr. Mahendra Pratap Choudhary, Associate Professor, Civil Engineering, Rajasthan Technical University, Kota, India. Email: choudhary_mp@yahoo.co.in

(C) The Authors. Published by Blue Eyes Intelligence Engineering and Sciences Publication (BEIESP). This is an open access article under the CC BY-NC-ND license (http://creativecommons.org/licenses/by-nc-nd/4.0/) river. In Delhi, due to large area and huge population, the network of sewerage and drainage system is inadequate and hence there is a need to lay down more sewer lines to connect with the sewerage system. To resolve the problem of direct discharge of wastewater into the river, sewage treatment plants (STPs) have been planned, designed and constructed by Delhi Jal Board so that the wastewater can be treated in an efficient way before its discharging into the rivers to reduce the problem of water pollution [1]. Delhi is the most populated city in India having a population of over 13.9 million and from the year 1971, the population has increased by up to $300 \%$. In Delhi city, the approximate quantity of sewage generated is about 600 MGD out of which only 512.4 MGD of wastewater is treated and hence only $85 \%$ of the total sewage is treated and the remaining $15 \%$ is disposed off directly into the Yamuna River [2]. According to the National River Conservation Directorate, the effluent standard parameters are placed in three categories. The first one is the removal of suspended solids and organic matter. The second is the removal of pathogenic bacteria and the third one is the removal of nutrients. The effluent quality of Najafgarh STP based on EA technology is found to be less efficient as compared to BIOFOR technology [3]. The Phytorid technology based STP, developed by the National Environmental Engineering Research Institute (NEERI) was found economical, requiring less area and easy in construction and maintenance and capable of removing organic solids and nutrients up to $95 \%$ which is suitable for irrigation and agriculture purposes [4].

\section{SCOPE OF THE STUDY}

The current study is based on the objective of finding removal efficiencies of various STPs located in Delhi which are based on different technologies. The three STPs were selected for the study namely Najafgarh, Delhi Gate and Shahdara based on EA, BIOFOR and Phytorid technologies respectively. This study is intended for the evaluation of wastewater quality and measuring the removal efficiencies which indicate the performance of each STP so as to select a suitable technology.

The samples of wastewater were obtained from the inlet and outlet points of STPs at Najafgarh, Delhi Gate and Shahdara during the period of six months from May 2019 to November 2019. The physic-chemical parameters of wastewater samples were analyzed in the laboratory for finding out the removal efficiencies. 


\section{Performance Assessment of Domestic Wastewater Treatment Plants Operating on Different Technologies}

\section{MATERIALS AND METHODS}

The Delhi Jal Board (DJB) is the only authority responsible for the sewerage and drainage works in Delhi. Some STPs are not functional because sufficient flow of wastewater is not available and the sewerage network is also insufficient [5].

The assessment of various STPs was performed for a period of 6 months for which necessary permission was taken from the DJB to collect the samples from inlet and outlet of the selected STPs. The samples were collected under the guidance of CSIR-NEERI, New Delhi. The wastewater samples were collected in standard sampling kits provided the NEERI, New Delhi. The samples for BOD, COD and ammonical nitrogen test were collected in plastic bottles of 1 liter and $500 \mathrm{ml}$ and preserved in an icebox at $4{ }^{\circ} \mathrm{C}$ above the freezing point. The 2 liters plastic bottle was used for the other physiochemical parameters and no preservation was needed. The influent and effluent quality was evaluated by performing various experiments such as COD, TSS, TDS, dissolved phosphate, $\mathrm{pH}, \mathrm{BOD}$, nitrate, sulphate, total alkalinity, electrical conductivity and chloride. These experiments were conducted as per the procedures of APHA [6]. Table I represents the details of various STPs, selected for the purpose of study. Figures 1 to 4 represent the inlet and outlet units of Najafgarh and Shahdara STPs.

Table I: Description of selected STPs

\begin{tabular}{|c|c|c|c|c|}
\hline $\begin{array}{c}\text { S. } \\
\text { No. }\end{array}$ & $\begin{array}{c}\text { Location of } \\
\text { STP }\end{array}$ & $\begin{array}{c}\text { Treatment } \\
\text { Technology }\end{array}$ & $\begin{array}{c}\text { Installed } \\
\text { Capacity }\end{array}$ & $\begin{array}{c}\text { Source of } \\
\text { Sewage }\end{array}$ \\
\hline 1 & Najafgarh & EA & 5 MGD & $\begin{array}{c}\text { Sewerage } \\
\text { system }\end{array}$ \\
\hline 2 & Delhi Gate & BIOFOR & 10 MLD & $\begin{array}{c}\text { Sewerage } \\
\text { system }\end{array}$ \\
\hline 3 & Shahdara & Phytorid & 3 MLD & $\begin{array}{c}\text { Sewerage } \\
\text { system }\end{array}$ \\
\hline
\end{tabular}

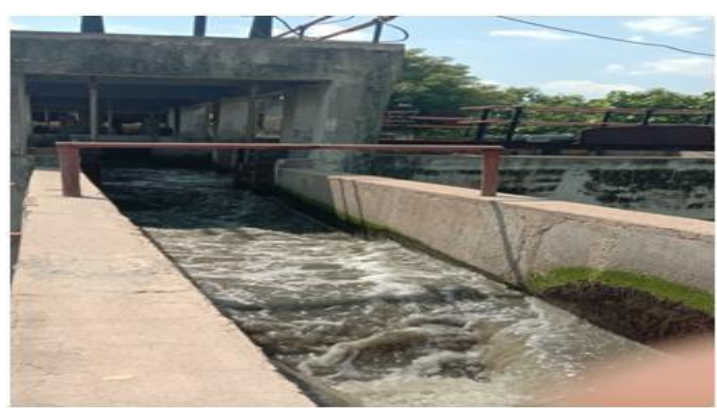

Fig 1: Inlet of STP at Najafgarh

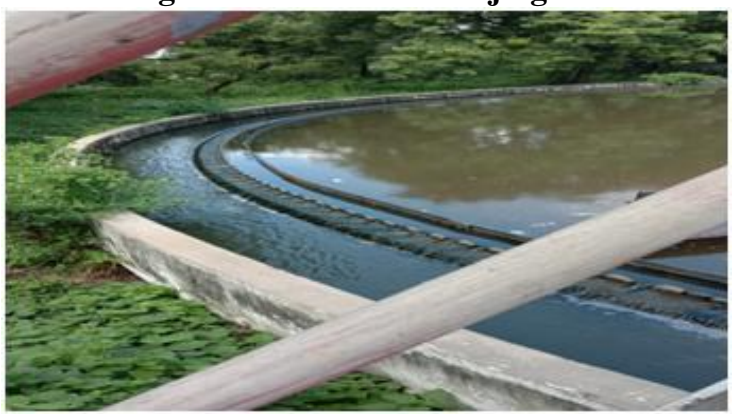

Fig 2: Outlet of STP at Najafgarh

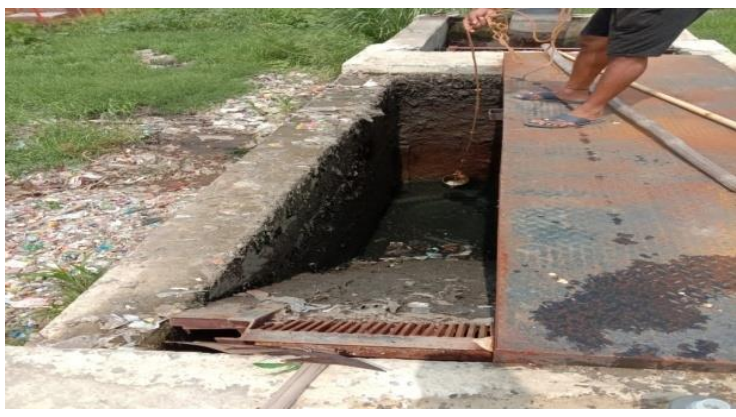

Fig 3: Inlet of STP at Shahdara

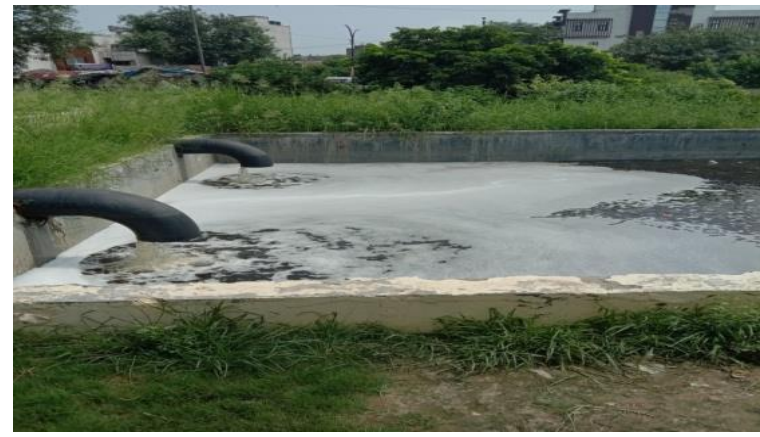

Fig 4: Outlet of STP at Shahdara

\section{RESULTS AND DISCUSSION}

Based on the samples collected from various STPs for their evaluation, the following results were obtained. Table II and III represent the physicochemical analysis and removal efficiencies of Najafgarh, Delhi Gate and Shahdara STPs based on EA, BIOFOR and Phytorid technologies.

Table II: Physico-chemical Analysis of STPs

\begin{tabular}{|c|c|c|c|c|c|c|}
\hline \multirow{2}{*}{ Parameters* } & \multicolumn{2}{|c|}{$\begin{array}{l}\text { Najafgarh STP } \\
\text { (EA) }\end{array}$} & \multicolumn{2}{|c|}{$\begin{array}{c}\text { Delhi Gate STP } \\
\text { (BIOFOR) }\end{array}$} & \multicolumn{2}{|c|}{$\begin{array}{c}\text { Shahdara STP } \\
\text { (Phytorid) }\end{array}$} \\
\hline & Inlet & Outlet & Inlet & Outlet & Inlet & Outlet \\
\hline $\mathrm{pH}$ & 7.08 & 7.48 & 7.11 & 6.86 & 7.1 & 7.6 \\
\hline $\begin{array}{c}\text { Electrical } \\
\text { conductivity } \\
\text { (in } \mu \text { s) }\end{array}$ & 1521 & 1127 & 1691 & 1161 & 1795 & 1348 \\
\hline $\begin{array}{l}\text { Turbidity (in } \\
\text { NTU) }\end{array}$ & 14 & 3.6 & 17 & 4.2 & 54 & 5.1 \\
\hline BOD & 210 & 22 & 190 & 7.3 & 200 & 8 \\
\hline COD & 576.8 & 90.64 & 379 & 41.2 & 609.76 & 28.84 \\
\hline Nitrate & 4.22 & 2.23 & 10.68 & 2.06 & 6.4 & 4.2 \\
\hline $\begin{array}{l}\text { Dissolved } \\
\text { Phosphate }\end{array}$ & 3.11 & 2.75 & 2.4 & 0.4 & 2.36 & 1.67 \\
\hline Sulphate & 135 & 115.85 & 119.4 & 81 & 99.7 & 37.5 \\
\hline $\begin{array}{l}\text { Ammonical } \\
\text { Nitrogen }\end{array}$ & 25.05 & 17 & 29.25 & 6.507 & 15.04 & 7.896 \\
\hline TSS & 547.69 & 128 & 656 & 17 & 686.7 & 88.57 \\
\hline TDS & 1192 & 485.71 & 1050 & 152.94 & 1840 & 390 \\
\hline $\begin{array}{c}\text { Total } \\
\text { Alkalinity } \\
\end{array}$ & 602 & 260 & 474 & 238 & 660 & 442 \\
\hline Chloride & 433 & 311 & 238 & 216 & 81 & 60 \\
\hline
\end{tabular}

*All parameters are in $\mathrm{mg} / \mathrm{l}$ except turbidity and electrical conductivity. 
Table III: Removal Efficiencies of STPs

\begin{tabular}{|c|c|c|c|}
\hline \multirow{2}{*}{ Parameters } & \multicolumn{3}{|c|}{ Removal Efficiencies (R.E. \%) } \\
\cline { 2 - 4 } & $\begin{array}{c}\text { Najafgarh } \\
\text { STP }\end{array}$ & $\begin{array}{c}\text { Delhi Gate } \\
\text { STP }\end{array}$ & $\begin{array}{c}\text { Shahdara } \\
\text { STP }\end{array}$ \\
\hline Turbidity & 74.2 & 75.29 & 90.6 \\
\hline BOD & 89.52 & 96.15 & 96 \\
\hline COD & 84.28 & 89.12 & 95.27 \\
\hline Nitrate & 47.15 & 80.71 & 34.37 \\
\hline $\begin{array}{c}\text { Dissolved } \\
\text { Phosphate }\end{array}$ & 11.57 & 83.33 & 29.23 \\
\hline Sulphate & 14.18 & 32.16 & 62.38 \\
\hline $\begin{array}{c}\text { Ammonical } \\
\text { Nitrogen }\end{array}$ & 32.13 & 77.75 & 47.5 \\
\hline TSS & 76.62 & 97.40 & 87.10 \\
\hline TDS & 59.25 & 85.43 & 78.80 \\
\hline $\begin{array}{c}\text { Total } \\
\text { Alkalinity }\end{array}$ & 56.81 & 49.78 & 33.03 \\
\hline Chloride & 28.17 & 9.24 & 25.92 \\
\hline
\end{tabular}

The range of BOD for all the three STPs is from 190 $\mathrm{mg} / \mathrm{l}$ to $210 \mathrm{mg} / \mathrm{l}$ for influent and $7.3 \mathrm{mg} / \mathrm{l}$ to $22 \mathrm{mg} / \mathrm{l}$ for $609.76 \mathrm{mg} / \mathrm{l}$ for influent and $28.84 \mathrm{mg} / \mathrm{l}$ to $90.64 \mathrm{mg} / \mathrm{l}$ for effluent.

The value of BOD content of treat wastewater for EA based STP is found to be highest which indicates the effluent consists of organic pollution due to problems or any fault in aeration treatment unit as compared to the other STPs. Turbidity variation is from $14 \mathrm{mg} / \mathrm{l}$ to $54 \mathrm{mg} / \mathrm{l}$ for treated wastewater and $3.6 \mathrm{mg} / \mathrm{l}$ to $5.1 \mathrm{mg} / \mathrm{l}$ for raw sewage. The $\mathrm{pH}$ levels are found to be constant for all STPs.

Conductivity is found to be the highest i.e. $1348 \mu \mathrm{S}$ and lowest i.e. $1127 \mu \mathrm{S}$ at the outlet for Phytorid technology based STP. The effluent of Delhi Gate STP is found to be slightly acidic but it is in the permissible limit as prescribed by the CPCB effluent standards [7]. The BIOFOR technology is found to have low BOD values which indicate proper chemical treatment. The COD value is highest for EA based STP which indicates presence of oxidizable organic matter in the treated wastewater and other STPs have low COD levels attributed to the low content of organic material present in the effluent.

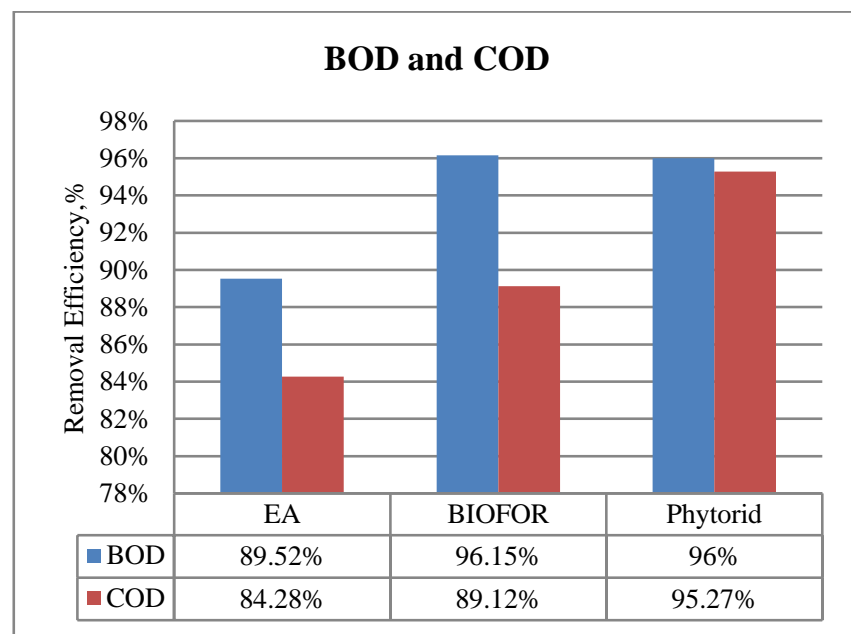

Graph 1: Removal Efficiency of BOD and COD effluent. Similarly, the range of COD is from $379 \mathrm{mg} / \mathrm{l}$ to

The Graph 1 depicts that the highest efficiency of removal of BOD and COD is for BIOFOR i.e. 96.15\% and 95.27\% for Phytorid based STP respectively. Similarly the lowest efficiencies for BOD and COD removal are observed for EA based STP i.e. 89.52\% and 84.28\%. The efficiency of EA technology based STP at Najafgarh is found to be less due to frequent breakdowns in power supply.

Graph 2 represents the removal efficiency in nitrate and dissolved phosphate. The range of nitrate removal is from $34.37 \%$ for Phytorid to $80.71 \%$ for BIOFOR technology. The removal efficiency of dissolved phosphate is from $11.57 \%$ for EA to $83.33 \%$ for BIOFOR technology. According to CPCB effluent standards for nitrate and dissolved phosphate, the treated wastewater qualities for all the STPs are within the permissible values and effluent can be disposed off into the surface water.

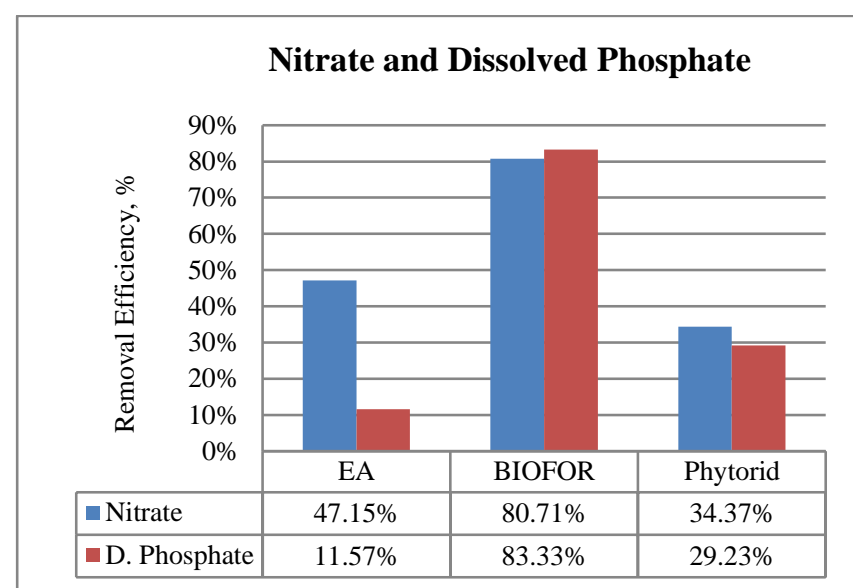

Graph 2: Removal Efficiency of Nitrate and Dissolved Phosphate

The values of sulphate vary from $99.7 \mathrm{mg} / \mathrm{l}$ to $135 \mathrm{mg} / \mathrm{l}$ at inlet and $37.5 \mathrm{mg} / \mathrm{l}$ to $115.85 \mathrm{mg} / \mathrm{l}$ at outlet. Graph 3 represents the removal efficiency of sulphate from $14.18 \%$ for EA to $62.38 \%$ for Phytorid technology. As per EPA guidelines [8], the allowable limit for sulphate in wastewater is $750 \mathrm{mg} / \mathrm{l}$. Hence, the treated wastewater from EA, BIOFOR and Phytorid based STPs is within the permissible limits for disposal on inland surface water sources.

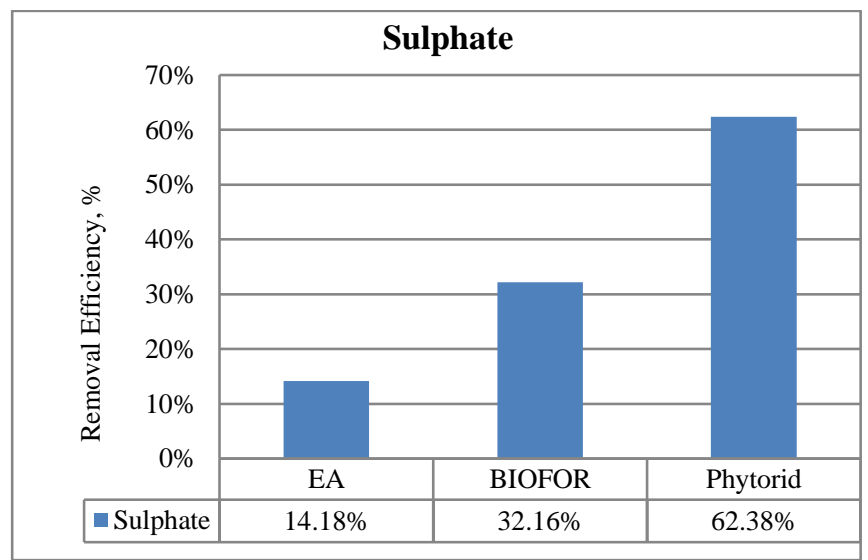

Graph 3: Removal Efficiency of Sulphate

Published By:

Blue Eyes Intelligence Engineering 
The variation in TSS and TDS values at outlet is within range from $17 \mathrm{mg} / \mathrm{l}$ to $128 \mathrm{mg} / \mathrm{l}$ and $152.94 \mathrm{mg} / \mathrm{l}$ to 485.71 $\mathrm{mg} / \mathrm{l}$ respectively. The highest value of TSS is $128 \mathrm{mg} / \mathrm{l}$ for EA based STP which is not in the permissible limit as prescribed by the CPCB effluent discharge standards. The possible reason may be improper working of screens and grit chamber. The other STPs are more efficient in removing TSS as their screening and sedimentation process are working properly.

The removal efficiencies for TSS and TDS are found to be highest as $97.40 \%$ and $85.43 \%$ for BIOFOR based STP as shown in Graph 4 below. Hence, the BIOFOR technology is more efficient to remove TSS and TDS as compared to the other technologies. The treated wastewater from the STP can safely be disposed off into surface water or may be applied for the irrigation.

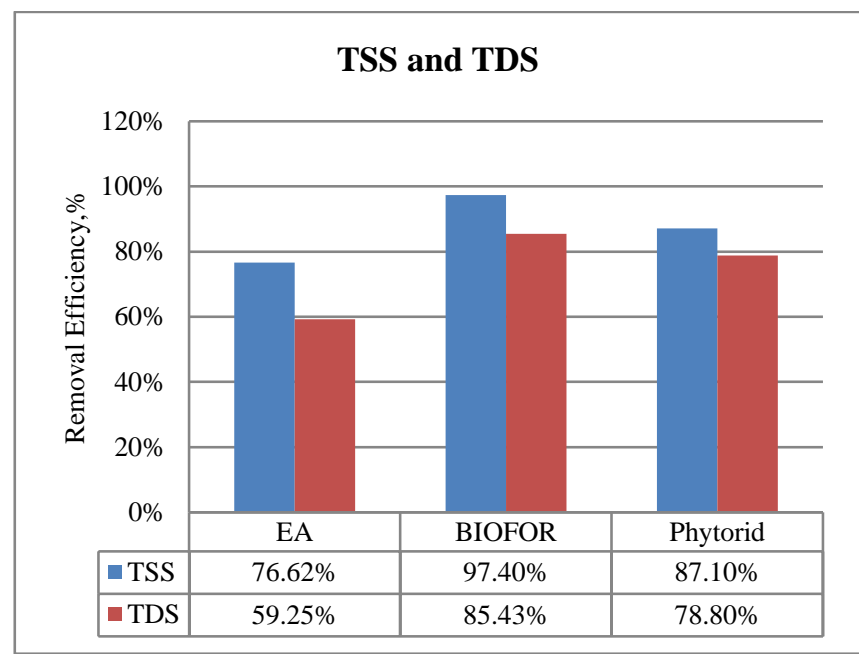

Graph 4: Removal Efficiency of TSS and TDS

The variation in ammonical nitrogen is the range from $15.04 \mathrm{mg} / \mathrm{l}$ to $29.25 \mathrm{mg} / \mathrm{l}$ for influent and $6.507 \mathrm{mg} / \mathrm{l}$ to 17 $\mathrm{mg} / \mathrm{l}$ for effluent. The highest removal rate is found $77.75 \%$ for BIOFOR based STP and lowest 32.13\% for EA based STP as shown in Graph 5. The removal of ammonical nitrogen is found to be less for EA and Phytorid based STPs due to slow nitrification process caused by improper aeration which increases nitrifying bacteria in the aeration unit and results in ammonia formation.

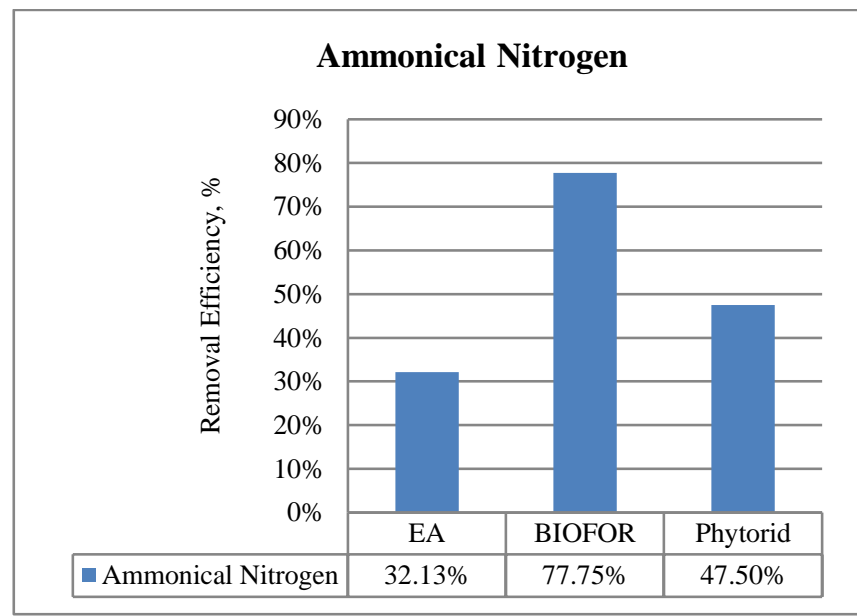

Graph 5: Removal Efficiency of Ammonical Nitrogen
The variation in total alkalinity for influent is from 474 $\mathrm{mg} / \mathrm{l}$ to $660 \mathrm{mg} / \mathrm{l}$ and $260 \mathrm{mg} / \mathrm{l}$ to $442 \mathrm{mg} / \mathrm{l}$ for effluent. According to WHO standards, the accepted level of chloride is $600 \mathrm{mg} / \mathrm{l}$.

The Graph 6 shows the removal efficiency in total alkalinity, which is highest for EA based STP i.e. 57\% and lowest for Phytorid based STP i.e. 3.03\%.

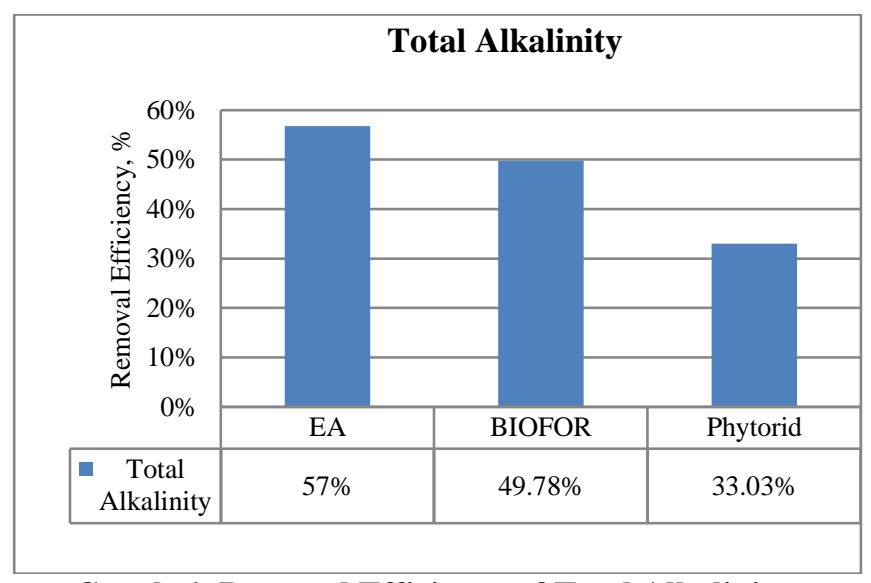

\section{Graph 6: Removal Efficiency of Total Alkalinity}

The variation in values of chloride at the inlet is from 81 $\mathrm{mg} / \mathrm{l}$ to $433 \mathrm{mg} / \mathrm{l}$ and at the outlet is from $60 \mathrm{mg} / \mathrm{l}$ to $311 \mathrm{mg} / \mathrm{l}$. the Graph 7 shows that the removal efficiency in chloride is from $9.24 \%$ for BIOFOR based STP to $28.17 \%$ for EA based STP. The chloride content in the effluent is in the permissible limit as per WHO standards and can be used for non-domestic purposes. The chloride in wastewater generally in the form of sodium chloride is due to anthropogenic sources and harmful for aquatic life.

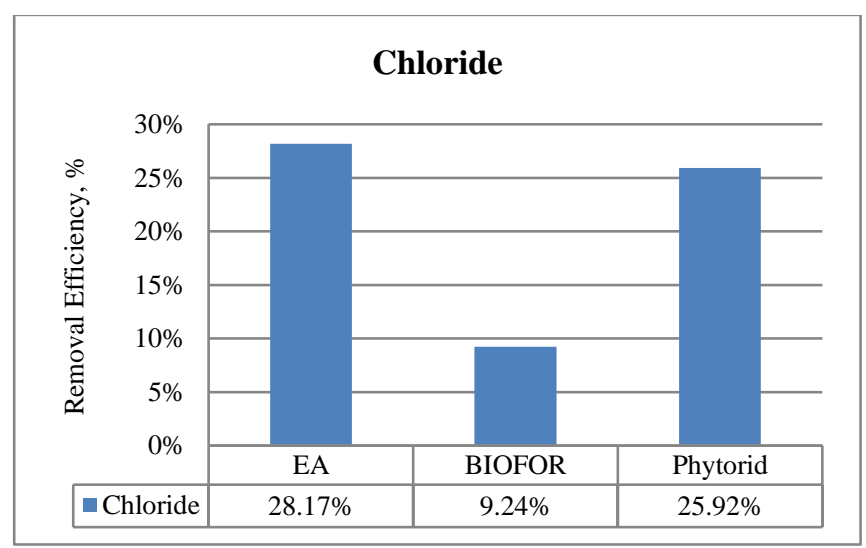

Graph 7: Removal Efficiency of Chloride

\section{CONCLUSION}

In present study, it is found that the BOD removal efficiency is highest for Delhi Gate STP based on BIOFOR technology and COD removal efficiency is highest for Shahdara STP based on Phytorid technology. The total suspended solids removal rate is highest for Delhi Gate STP. The other parameters for BIOFOR and Phytorid based STPs are also within the permissible limit as per Indian standards with good removal efficiencies. 
The effluent quality from Najafgarh STP which is based on extended aeration (EA) technology is found to be less efficient and this technology is not able to produce better quality of effluent. Therefore, it is concluded that Najafgarh STP needs to be operated, maintained and monitored regularly to improve the efficiency of treatment plant. The irregular power supply is also one of the reason behind the low efficiency of the Najafgarh STP causing unequalized flow in the STP. However, the quality of effluent for other STPs are satisfactory and can be disposed off into surface water or can be used for agricultural and irrigation purposes.

\section{ACKNOWLEDGMENT}

The authors acknowledge their sincere gratitude to the CSIR-NEERI Zonal Centre Delhi and especially Dr. Raman Sharma, Senior Scientist for helping out in laboratory experiments and guiding during the research work.

\section{REFERENCES}

1. Harish Uniyal, Trimurti Narayan Pandey, Ujala Mishra and Bharat Phulwari "Effect on Water Quality of Yamuna River Due to Discharge of Open Drains in Delhi”, IRJET, Volume: 06, Issue 02, p-ISSN: 2395-0072, 2019

2. Rajneesh K. Gautam , Islamuddin , Nandkishor More, Saumya Verma , Spriha Pandey, Neha Mumtaz, Rajesh Kumar and Md. Usama "Sewage Generation and Treatment Status for the City of Delhi, its Past, Present and Future Scenario", IJRASET, Volume 5, Issue 05, 2017

3. Priyanka Jamwal, Atul K. Mittal and Jean-Marie Mouchel "Efficiency evaluation of sewage treatment plants with different technologies in Delhi" Environmental Monitoring and Assessment, DOI 10.1007/s10661-008-0356-9, 2009

4. R. Kaalipushpa, S. Karthika and S. Revathi "Domestic Wastewater Treatment using Phytorid Technology", IJERT, Volume 5, Issue 13, 2017

5. CPCB "Inventorization of Sewage Treatment Plants", Ministry of Environment and Forests, Govt. of India: CUPS/61/2005-06, Central Pollution Control Board, India, 2007

6. APHA, Standard Methods for the Examination of Water and Wastewater, 20th edition, American Public Health Association, Washington,1998

7. CPCB"General Standards for Discharge of Environmental Pollutants Part-A: Effluents", Environment (Protection) Rules, Schedule-4, Central Pollution Control Board, India,1986

8. United States Environmental Protection Agency "National Recommended Water Quality Criteria”,2002

\section{AUTHORS PROFILE}

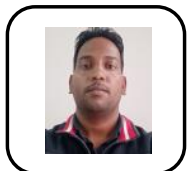

Sudhir Kumar is pursuing Post Graduate Degree in Engineering with specialization of Environmental Engineering from the Rajasthan Technical University, Kota in the Civil Engineering department. Sudhir graduated in Civil Engineering from Sir Padampat Singhania University Udaipur in 2015.

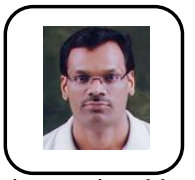

Dr. Mahendra Pratap Choudhary is Associate Professor in the department of Civil Engineering at Rajasthan Technical University, Kota. Dr. Choudhary has guided more than $15 \mathrm{M}$. Tech. students and about 55 research papers have been published in national and international level conference and journals. 